\title{
AVASCULAR NECROSIS OF THE FEMORAL CAPITAL EPIPHYSIS AFTER TRAUMATIC DISLOCATION OF THE HIP IN CHILDREN*
}

\author{
Robert A. Haliburton, Freeman A. Brockenshire and John R. Barber, \\ Windsor, ONTARIO, CANADA
}

Traumatic dislocation of the hip in children is uncommon. Fineschi (1956) in a careful review of the literature stated that there were about 150 reported cases, of which sixteen were complicated by avascular necrosis of the femoral capital epiphysis. The purpose of this paper is to review the literature on such cases and to report an additional case.

We have been able to review thirteen cases of avascular necrosis of the femoral capital epiphysis after traumatic dislocation of the hip reported by Elmslie (1919),

TABLE I

A Summary of Cases of Avascular Necrosis of Femoral. Capital Epiphysis after Traumatic Dislocation of the Hip

\begin{tabular}{|c|c|c|c|c|c|c|}
\hline Author & Year & $\begin{array}{c}\text { Age } \\
\text { (years) }\end{array}$ & Sex & $\begin{array}{c}\text { Type of } \\
\text { dislocation }\end{array}$ & $\begin{array}{l}\text { Interval } \\
\text { between } \\
\text { injury and } \\
\text { reduction }\end{array}$ & $\begin{array}{c}\text { Interval } \\
\text { between injury } \\
\text { and diagnosis } \\
\text { of avascular } \\
\text { necrosis } \\
\text { (months) }\end{array}$ \\
\hline Banks & 1941 & 12 & $\mathbf{M}$ & Anterior & - & 15 \\
\hline Böhler & 1957 & 8 & $\mathrm{~F}$ & Posterior & 8 days & 12 \\
\hline $\begin{array}{l}\text { Chandler and } \\
\text { Kreuscher }\end{array}$ & 1932 & 14 & $\mathrm{~F}$ & Central & - & 6 \\
\hline Elmslie & 1919 & 4 & $\mathbf{M}$ & Posterior & I week & 15 \\
\hline Elmslie & 1932 & 7 & $F$ & Posterior & 1 week & 9 \\
\hline Fairbank & 1924 & $10 \frac{1}{2}$ & $\mathbf{M}$ & Posterior & 3 days & 7 \\
\hline Goldenberg & 1938 & $10 \frac{1}{2}$ & $\mathbf{M}$ & Posterior & I week & 28 \\
\hline Kleinberg & 1939 & 15 & $\mathbf{M}$ & Posterior & - & 13 \\
\hline Mutschler & 1939 & 13 & M & Posterior & - & 12 \\
\hline Phemister & 1934 & 14 & F & Posterior & - & 11 \\
\hline Quist-Hanssen & 1945 & 4 & $\mathbf{M}$ & Posterior & 3 days & 8 \\
\hline Rehbein & 1922 & 8 & $\mathbf{M}$ & Posterior & 1 day & 12 \\
\hline Watson-Jones & 1940 & 14 & $F$ & Posterior & 1 day & 3 \\
\hline
\end{tabular}

In all cases deformity of the femoral head of the type associated with Perthes' disease developed.

Rehbein (1922), Fairbank (1924), Elmslie (1932), Chandler and Kreuscher (1932), Phemister (1934), Goldenberg (1938), Kleinberg (1939), Mutschler (1939), Banks (1941), Quist-Hanssen (1945), Watson-Jones (1940), and Böhler (1957) (Table I). The age of the patients varied from four to fifteen years. There were eight boys and five girls. The side of the dislocation was stated in only five cases (three right and two left). The dislocation was posterior in eleven patients, anterior in one and central in one. The interval

* Paper read at the annual meeting of the Canadian Orthopaedic Association, St Marguerite, Quebec, Canada, on June 29, 1959. 
between injury and reduction was given in eight case reports: the shortest was one day, the longest eight days. The time interval between the injury and the diagnosis of avascular necrosis varied from three to twenty-eight months. All the patients had consequent radiographic deformity of the head and neck of the femur. The radiographic appearances led early observers to consider a causal relationship between trauma and Legg-Perthes' disease.

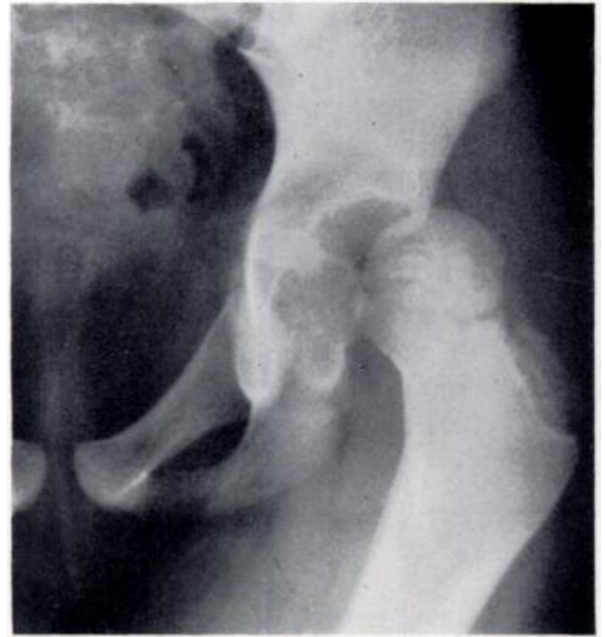

Fig. 1

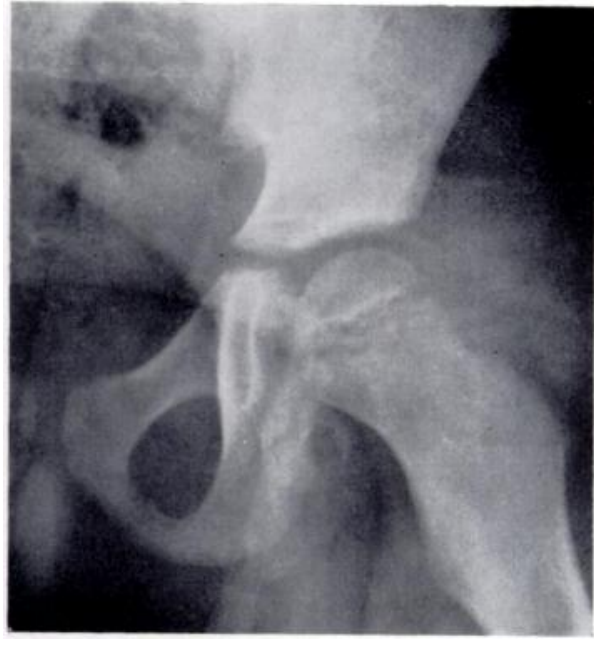

FIG. 2

Figure 1-Initial radiograph before reduction. Figure 2-Immediately after reduction (in plaster).

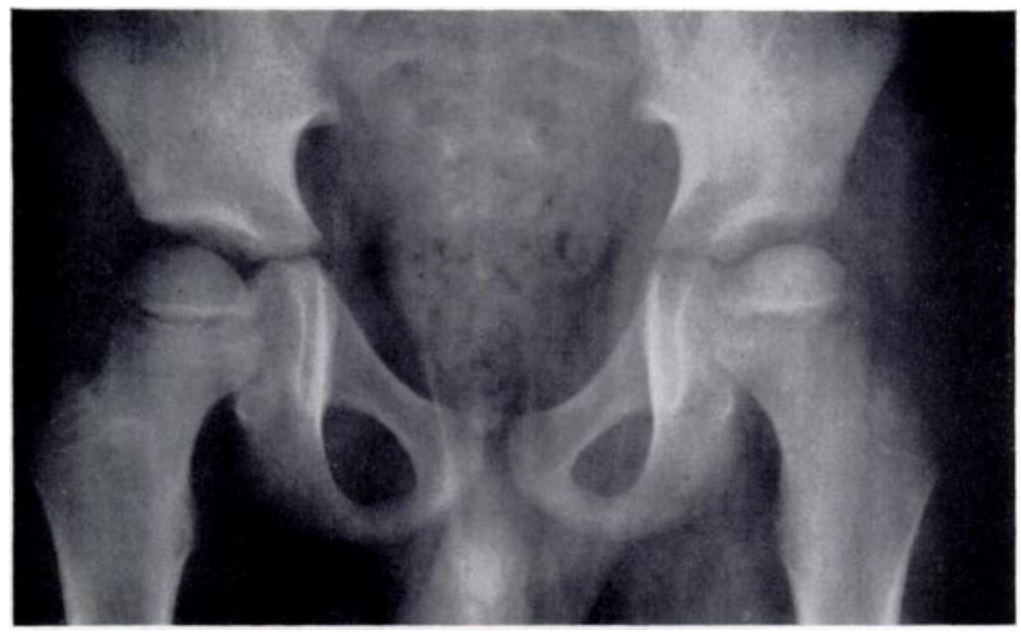

Fig. 3

Two months later on removal of plaster. There is uniform, increased radioopacity of the left femoral capital epiphysis, compared with the unaffected side.

\section{CASE REPORT}

In July 1958 a seven and a half-year-old boy's left hip was injured when a larger boy fell on him during play. When seen two hours after injury he had severe pain in the hip. The lower limb was held flexed and adducted, and there was a bony prominence in the left buttock. There was no evidence of damage to nerves or vessels. The radiograph (Fig. 1) showed a posterior dislocation of the left hip without fracture. Three hours after injury, under general anaesthesia with sodium pentothal and Flaxedil, the dislocation was reduced by flexion of the hip and knee and traction on the thigh with the pelvis held by an assistant. Reduction was 
moderately difficult. The hip was immobilised in a plaster spica in extension and abduction. The radiograph (Fig. 2) showed concentric reduction. Radiographs taken two days, one week and three weeks after the injury showed maintenance of reduction. The plaster was removed after eight weeks. At that time radiographs (Fig. 3) showed uniform, increased radio-opacity of the left femoral capital epiphysis as compared with the unaffected side. A diagnosis of avascular necrosis of the left femoral capital epiphysis was made and the patient was kept in bed. One month later radiographs showed no change in the appearance of the left hip, and the patient was allowed up with crutches and a sling for the affected leg. Two months after

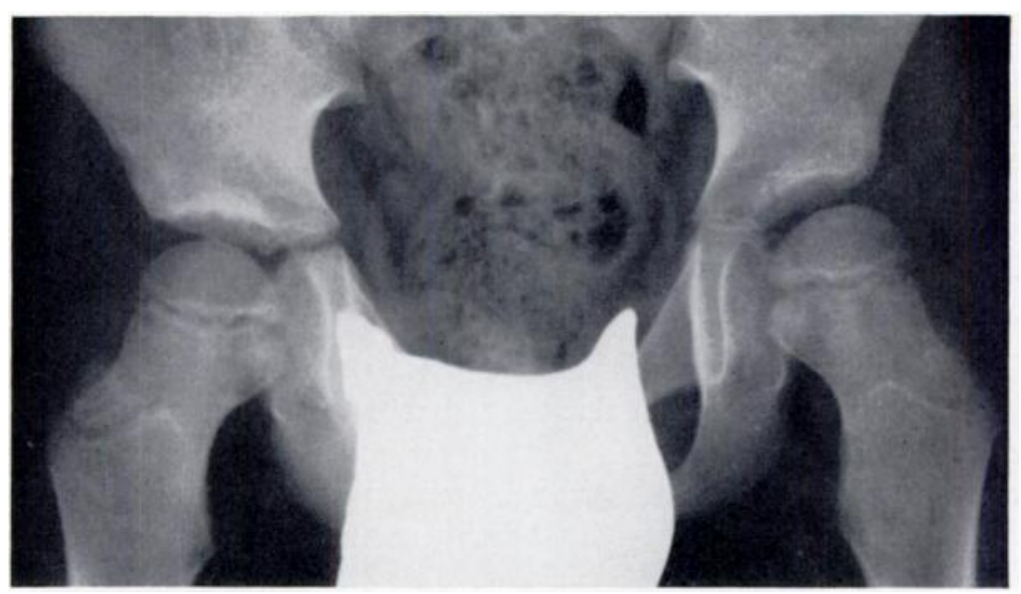

FIG. 4

Five months after dislocation the hip appears normal.

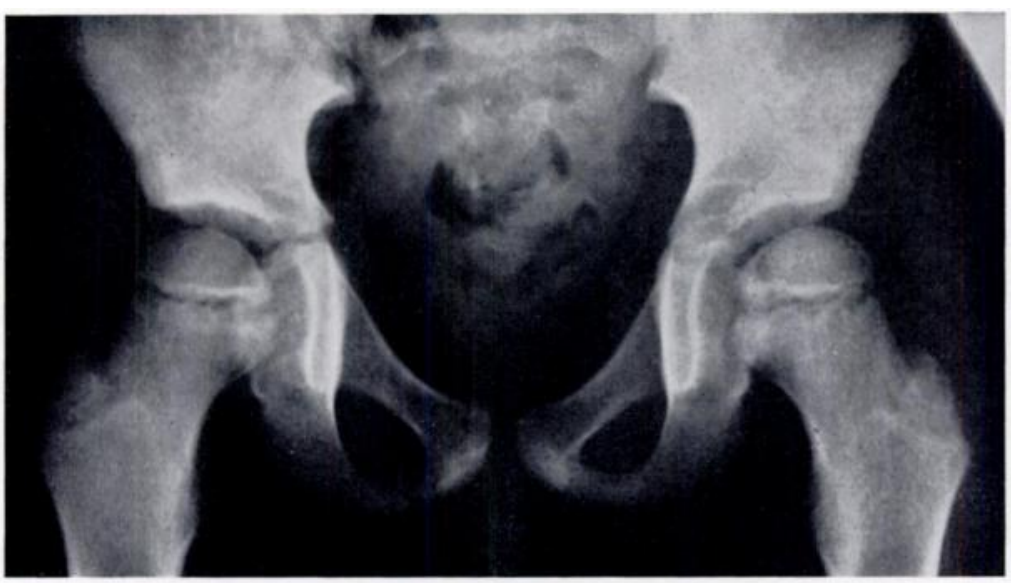

Fig. 5

Appearance of hips one year after the injury.

this there was a full painless range of motion in the left hip, and a radiograph at that time (Fig. 4) showed a normal appearance of both hips. The patient was not allowed to bear weight on the affected leg until six months after the injury. Since then his hip has remained clinically and radiologically normal. The appearance of the hips one year after the injury is shown in Figure 5.

\section{DISCUSSION}

The normal vascular anatomy of the femoral capital epiphysis has been described by Trueta (1957). At the age of seven and a half years the proximal femoral epiphysis is supplied 
with blood by the lateral epiphysial arteries which enter the epiphysis posteriorly and laterally, and by arteries in the ligamentum teres. That avascular necrosis of the femoral capital epiphysis should occur after posterior dislocation of the hip at this age is not surprising, indeed it is almost to be expected. The patient described developed avascular necrosis of the upper femoral epiphysis after traumatic posterior dislocation of the hip, which was diagnosed eight weeks after injury, despite early and maintained concentric reduction. It is of significance that within five months of the injury the proximal femoral epiphysis regained normal radiographic density without fragmentation or collapse. Replacement of the epiphysis in Legg-Perthes' disease does not occur so rapidly, and usually there is some resultant deformity of the femoral head and neck. Ponseti (1956) believed that avascular necrosis in Legg-Perthes' disease was secondary to a primary pathological process in the epiphysial plate. Legg-Perthes' disease differs fundamentally from avascular necrosis after traumatic dislocation of the hip; in the latter condition the epiphysial plate may be normal and replacement of the epiphysis can occur in a surprisingly short time with adequate treatment.

\section{SUMMARY}

1. The case history of a seven and a half-year-old boy who developed increased radiographic density of the femoral capital epiphysis after traumatic dislocation of the hip is presented.

2. The authors have been able to examine the case reports of thirteen similar cases presented in the literature.

3. The case presented is felt to be of interest because avascular necrosis was diagnosed early, and the radiographic appearance of the hip became normal five months after the injury.

\section{REFERENCES}

Banks, S. W. (1941): Aseptic Necrosis of the Femoral Head Following Traumatic Dislocation of Hip. Journal of Bone and Joint Surgery, 23, 753.

BöHLER, J. (1957): Die sogenannten Schenkelkopfnekrosen nach traumatischen Hüftverrenkungen. Wiederherstellungschirurgie und Traumatologie, 4, 75.

Chander, S. B., and Kreuscher, P. H. (1932): A Study of the Blood Supply of the Ligamentum Teres and its Relation to the Circulation of the Head of the Femur. Journal of Bone and Joint Surgery, 14, 834.

ElmsLie, R. C. (1919): Pseudocoxalgia Following Traumatic Dislocation of the Hip in a Boy aged Four Years. Journal of Orthopaedic Surgery, 1, 109.

Elmsle, R. C. (1932): Traumatic Dislocation of the Hip in a Child aged 7, with Subsequent Development of Coxa Plana. Proceedings of the Royal Society of Medicine (Section of Orthopaedics), 25, 1,100.

Fairbank, H. A. T. (1924): Case of Pseudo-Coxalgia Following Traumatic Dislocation in a Boy. Proceedings of the Royal Society of Medicine (Section of Orthopaedics), 17, 40.

FINESCHI, G. (1956): Die traumatische Hüftverrenkung bei Kindern. Literaturübersicht und statistischer Beitrag von 7 Fällen. Archiv für Orthopädische und Unfall-Chirurgie, 48, 225.

GoldenberG, R. R. (1938): Traumatic Dislocation of the Hip Followed by Perthes' Disease. Journal of Bone and Joint Surgery, 20, 770.

Kleinberg, S. (1939): Aseptic Necrosis of the Femoral Head Following Traumatic Dislocation. Report of Two Cases. Archives of Surgery, 39, 637.

MUTSCHLER, H. H. (1939): Sekundäre Oberschenkelkopfnekrose nach traumatischer Ausrenkung des Hüftgelenkes bei einem 14 Jährigen. Münchener Medizinische Wochenschrift, 86, 258.

Phemister, D. B. (1934): Fractures of Neck of Femur, Dislocations of Hip, and Obscure Vascular Disturbances Producing Aseptic Necrosis of Head of Femur. Surgery, Gynecology and Obstetrics, 59, 415.

PonseT, I. V. (1956): Legg-Perthes Disease. Observations on Pathological Changes in Two Cases. Journal of Bone and Joint Surgery, 38-A, 739.

Quist-Hanssen, Sv. (1945): Caput Necrosis After Traumatic Dislocation of the Hip Joint in a 4-year old Boy, and Control Examinations of 8 Cases of Luxatio Coxae Traumatica. Acta Chirurgica Scandinavica, 92, 393.

RehbeIN, M. (1922): Zur Ätiologie der Perthesschen Krankheit, zugleich ein Beitrag zur traumatischen Hüftgelenksluxation im Kindesalter. Deutsche Zeitschrift für Chirurgie, 174, 416.

Trueta, J. (1957): The Normal Vascular Anatomy of the Human Femoral Head During Growth. Journal of Bone and Joint Surgery, 39-B, 358.

WATSON-JoNes, R. (1940): Fractures and Other Bone and Joint Injuries, p. 69. Edinburgh: E. \& S. Livingstone Ltd. 